$\xi=-1$

\title{
Technology-based Business Incubator Model as Efforts to Improve the Learning Process
}

\author{
Ratih Hurriyati ${ }^{1 *}$, Ana $A^{2}$, R. Hassan ${ }^{3}$, Lai C. $S^{3}$ \\ ${ }^{1}$ Management and Business Education Department, Faculty of Economic and Business Education UPI, Indonesia \\ ${ }^{2}$ Home Economics Education Department, Faculty of Technology and Vocational Education UPI, Indonesia \\ ${ }^{3}$ Engineering Education Department, Faculty of Technical and Vocational Education, University Tun Hussein Onn Malaysia (UTHM), \\ Malaysia \\ *Corresponding author E-mail: ratih@upi.edu
}

\begin{abstract}
This paper tries to identify technology-based business incubator models as an effort to improve the right learning process. The method used is an experimental method, where in the early stages the criteria for learning technology-based business incubator learning criteria are developed by integrating pedagogical aspects and technological aspects that will be used as experiments through need assessment, then proceed with making a model design. Model design based on the teaching model that will be applied. In the next stage, the implementation of the trial was carried out by using the teaching model and the entrepreneurship courses that were set, and then conducted a trial on the technology-based business incubator learning system with the same teaching model and courses and the same students. The results of this study produce a learning system that is able to create individuation, acceleration, enrichment, expansion, effectiveness and productivity of learning which in turn will improve the quality of education as an overall human-resource development infrastructure.
\end{abstract}

Keywords: technology-based business incubator; learning model; entrepreneurship.

\section{Introduction}

Technology-based business incubators are designed to help students how to create or establish new and developing businesses so that they are well-established and able to make a profit by providing information, consulting, services and other support. Business incubators have been developed by universities with various approaches and targets. With the Business Incubator, it is expected that universities will be able to implement the knowledge that is owned and participate in the community service program more significantly. Namely growing new entrepreneurs who are able to develop small and medium micro enterprises (SMEs)

Research on the contribution of technology-based business incubators to economic growth began to gain momentum in the 1980s, following the growing phenomenon of business incubation [20], [21-23]. In the 1990s most of the research analyzed data from the US, where technology clusters and techno poles developed around technology generators such as universities, national laboratories, private research and development (R \& D) laboratories and other high-tech companies [1-2] in recent [3-10] provide evidence from Canada, Denmark, Greece, Italy, Korea, Norway and Portugal Business incubators (in various forms, such as industrial parks, science parks or technology innovation centers) are institutions that help new entrepreneurs in starting their businesses to improve development prospects and resilience, so that they can survive in the real business environment [11].

Technology-based business incubator was one of the learning models is expected to be one of the learning models that will foster student independence. Internally, the creation of innovations from inventions in universities will continue to grow due to commercialization activities. Technology-based business incuba- tors also remain a part of the education process, especially real learning about how to create value added creation, increase professionalism, be responsible, create reliable entrepreneurs [24-26], and how to form a business community in higher education. Going forward, technology-based business incubators are expected to be one of the spearheads in an effort to maintain their independence. Furthermore, it must be able to be a mediator to encourage the creation and growth of social wealth creation. This research aims: How is technology based business incubator model as effort to improve the learning process in university.

\section{Methodology}

The design that will be used in this study, which is using the experimental method, where in the initial stage is designed the criteria for learning technology-based business incubator model through the integration of pedagogical aspects and technological aspects that will be used as an experiment through need assessment, then proceed with making a model design.

The design of a technology-based business incubator learning model based on the teaching model that will be applied. In the next stage, the implementation during the implementation of technology-based business incubator learning model using teaching models and entrepreneurship courses was carried out, then conducted a trial on the technology-based business incubator learning system with the same teaching model and courses and the same students.

In the process of testing the implementation of technology-based business incubator learning models, all learning activities are recorded with a video camera. Interviews were conducted on students and lecturers after the implementation was carried out, to find out 
their opinions from the trial data model from interviews and recordings are then analyzed according to the criteria and guidelines that have been made, then an initial research report is made from the results of testing the implementation of the next stage of mak ing guidelines, dissemination and dissemination of technologybased business incubator learning models by inviting parties involved. Academics for more details can be seen in Figure 1.

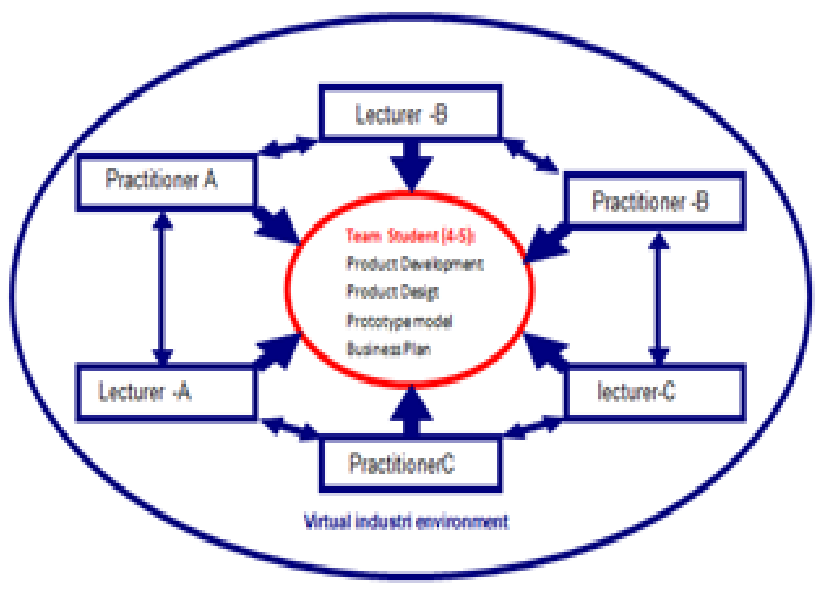

Fig. 1: Learning process through technology-based business incubators

\section{Results and Discussion}

Application of technology-based business incubators in the learning process at universities can facilitate the interaction between students with material or lecture material. Students can share information or opinions about various matters related to lecturing material or their self-development needs. In addition, lecturers can place learning materials and tasks that must be done by students in specific places on the web to be accessed. In accordance with needs, lecturers can also provide opportunities for students to access certain learning materials and exam questions that can only be accessed by students once and within a certain time span [12]. When drawn the primacy of the learning process using technology-based business incubators are as follows can be seen Figure 2 .

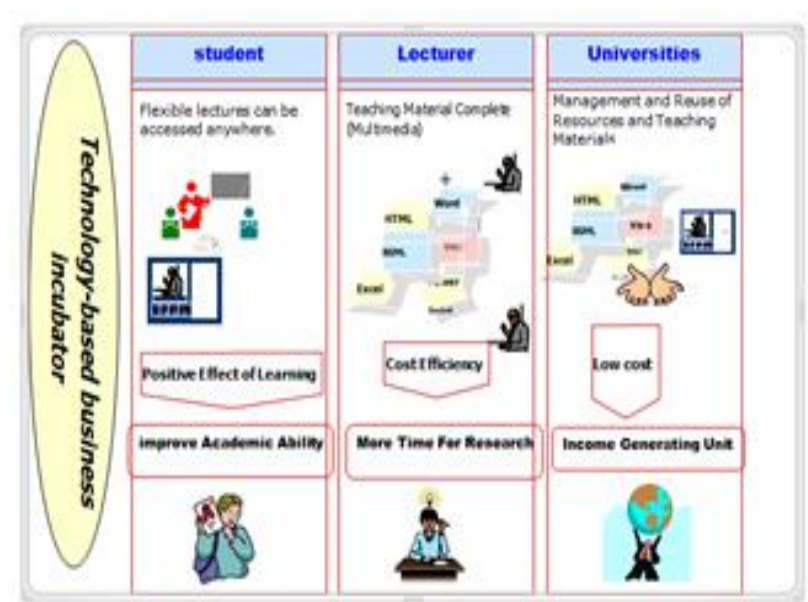

Fig. 2: The virtue of the learning process through technology-based business incubators

As one form of innovative learning models, technology-based business incubator learning models have advantages, including: (1) Providing different learning experiences. Thus, it can overcome boredom and boredom in learning with ordinary methods, (2) Overcoming problems of time and place. (3) Through this model one can do learning easily anytime and anywhere by using a computer connected to the Internet network (4) Establishing independent learning awareness (5) Cost reduction (6) High flexibility (7) Personalization. Students can learn according to their learning abilities. (8) Standardization. Through this learning, model can anticipate differences derived from teachers, such as: how to teach, material and mastery of different material, to provide a more consistent quality standard. (9) Speed. The speed of distribution of lecture material will increase, because the lecture material can be quickly delivered through technology

However, this technology-based business incubator learning model also has drawbacks such as (1) Lack of interaction between teachers and students or between fellow students reduce the function of humans as social beings. (2) Some lecture material requires practice that must be directly under the guidance of the teacher. (3) Problems of skills and knowledge, not everyone understands computers and the Internet (4) Lack of interaction between teachers and students or even between students themselves, which can slow the formation of values in the learning and teaching process. (5) The tendency to ignore academic aspects or social aspects and vice versa to encourage the growth of business aspects (6) Students, who do not have high learning motivation tend to fail.

Understanding of the learning environment emphasizes the role played by the teacher, the role of students during learning, the format of instruction and learning strategies themselves. An effective learning environment will produce optimum learning outcomes so that in the end it will lead to the ability of students to apply knowledge to actual life experiences to solve problems.

The rapid development of Information Technology, there has been a shift in views about learning both in lecture halls and outside lecture halls. In the traditional view of the past (and still in the present), the learning process is seen as: (1) something difficult and heavy, (2) efforts to fill the shortage of students, (3) a process of transfer and receipt of information, (4) individual or solitary processes, (5) activities carried out by describing the lecture material to small and isolated units, (6) a linear process

In line with its development, there has been a change in views regarding learning, namely learning as: (1) natural processes, (2) social processes, (3) active and passive processes, (4) linear and or non-linear processes, (5) integrative ongoing processes and contextual, (6) activities based on the student's model of strengths, skills, interests, and curriculum, (7) activities that are assessed based on task fulfillment, results from acquisition, and solving real problems both individually and in groups. The role of the lecturer has changed from: (1) as a transmitter of knowledge, the main source of information, expert material, and the source of all answers, become facilitators of learning, coach, collaborator, navigator of knowledge and learning partner; (2) of controlling and directing all aspects of learning, become more provide more alternatives and responsibilities for every student in the process of Learning. Lecturers as: coaches (coaches), counselors, learning manager, participant, leaders, learners, and authors [13].

Meanwhile, the role of students in learning has undergone changes namely: (1) from passive recipients of information to active participants in the learning process, (2) from re-revealing knowledge to produce and various knowledge, (3) from learning as individual activities (solitary) become collaborative learning with other students.

The presence of the technology-based business incubator in the business environment is a synergy between the business practitioners with academics on the development of the strategic environment, especially the changing demands and behavior. The changes are grouped into: first, emerging markets. Second, the second curve of the life cycle. Third, the environmental sound business practices. Fourth, the quest for competitiveness. Fifth, quality trends. Sixth, the economic crisis turbulence. Seventh, electronic and virtual competition

Approach model adapted for the prototype of a technology-based business incubator model are an entrepreneurial education model that can produce educated entrepreneurs [14, 19], for more details can be seen in Figure 3. 


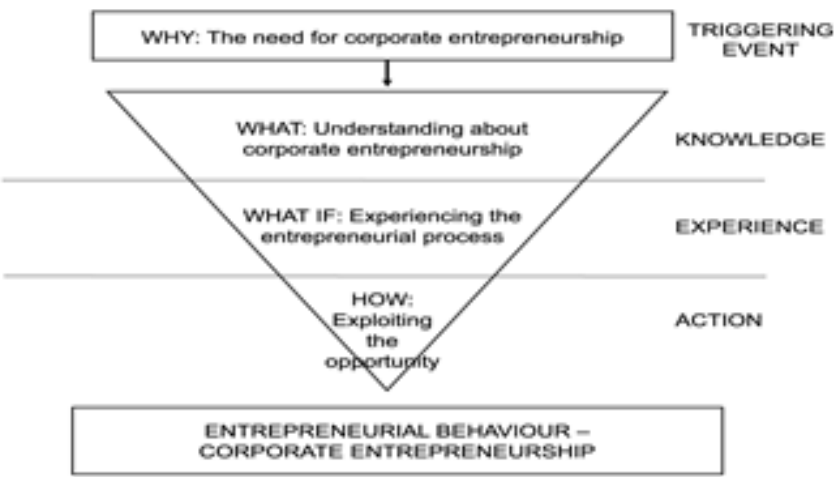

Fig. 3: Learning Approach to Entrepreneurship in Higher Education

Based on the specifications of the needs problem that has been made, the design of the learning source component for the development of entrepreneurial competencies that will be applied is the design of this entrepreneurial learning source taken from [15-16] can be seen in Figure 4.

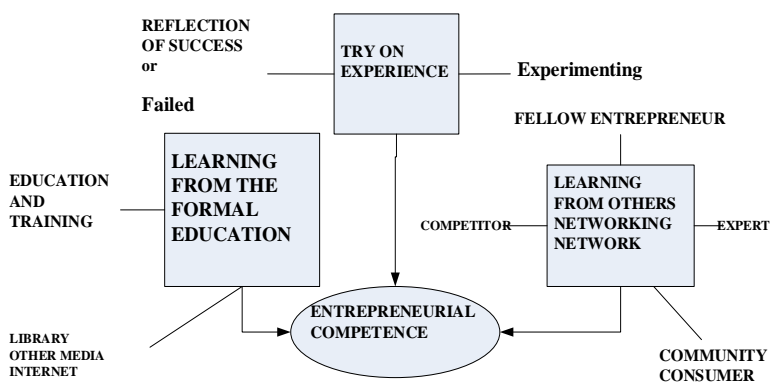

Fig. 4: Entrepreneurial learning resources

Prototype The model for developing technology-based business incubators is one of the models for developing entrepreneurship education learning in PT, not only producing entrepreneurs who are able to establish new businesses that are usually small business (new business startup) businesses. The learning model approach used is The Generic action approach which emphasizes the learning process through the activities carried out, this approach is somewhat different from the case that there was no previous solution to a problem and always questioned the assumption of each proposed alternative [17, 27]. In this learning model approach, students are given a highly contextual solution. Students not only discuss the practical implications of the solution but also the consequences that arise from the concepts and theories used, thus learning actions not only emphasize the experience gained while undergoing an activity but also have a strong knowledge base before carrying out these activities. Students are not only skilled at mastering concepts that will be used in solving problems but also enriching their insights. Students are trained to conceptualize their experiences (theorizing their experience) through the preparation of learning points obtained from each activity. Modeling Results of this technology-based business incubator produce the following objectives can be seen Table 1:

Table 1: Modeling Results of Technology Based Business Incubator Produce

\begin{tabular}{|c|l|l|}
\hline Goals & \multicolumn{1}{|c|}{ Competencies } & \multicolumn{1}{c|}{ Indicators } \\
\hline To & $\begin{array}{l}\text { Knowing and understanding the } \\
\text { meaning of Entrepreneurship, } \\
\text { Entrepreneurship. Entrepreneur } \\
\text { and the key to success (success } \\
\text { story) and entrepreneurial value }\end{array}$ & $\begin{array}{l}\text { Being able to express } \\
\text { themselves in verbal, } \\
\text { written, mindset and } \\
\text { attitude entrepreneur- } \\
\text { ial }\end{array}$ \\
\hline To & $\begin{array}{l}\text { Increasing understanding of en- } \\
\text { trepreneurship through positive } \\
\text { (positive image) and entrepre- } \\
\text { neurial values }\end{array}$ & $\begin{array}{l}\text { Knowing the role of } \\
\text { motivation and spirit } \\
\text { of entrepreneurship }\end{array}$ \\
\hline To & $\begin{array}{l}\text { Understanding the Components } \\
\text { of Entrepreneurship Education } \\
\text { through creativity, innovation and }\end{array}$ & $\begin{array}{l}\text { Knowing the role of } \\
\text { creativity, innovation } \\
\text { and risk taking in }\end{array}$ \\
\hline
\end{tabular}

\begin{tabular}{|c|l|l|}
\hline & risk taking analysis. & entrepreneurship \\
\hline To Do & $\begin{array}{l}\text { Understand the concepts of effi- } \\
\text { ciency, economics and socio- } \\
\text { culture in the context of entrepre- } \\
\text { neurship and entrepreneurial } \\
\text { behavior }\end{array}$ & $\begin{array}{l}\text { Understanding entre- } \\
\text { preneurial behavior } \\
\text { and basic communi- } \\
\text { cation }\end{array}$ \\
\hline To Do & $\begin{array}{l}\text { Understand the specific role of } \\
\text { entrepreneurial skills (team work) } \\
\text { and the knowledge needed for } \\
\text { social or commercial activities }\end{array}$ & $\begin{array}{l}\text { Increased digital } \\
\text { skills, basic econom- } \\
\text { ics and finance }\end{array}$ \\
\hline To Do & $\begin{array}{l}\text { Understanding the role of the } \\
\text { organization, managing conflict } \\
\text { and negotiation, the entrepreneur- } \\
\text { ial way of life, ability to plan }\end{array}$ & $\begin{array}{l}\text { Increased capacity } \\
\text { planning and imple- } \\
\text { menting }\end{array}$ \\
\hline To be & $\begin{array}{l}\text { Understand the techniques and } \\
\text { strategies to realize ideas into } \\
\text { action (business start-up) }\end{array}$ & $\begin{array}{l}\text { The increasing num- } \\
\text { ber of business plans } \\
\text { that are feasible and } \\
\text { realized }\end{array}$ \\
\hline To Be & $\begin{array}{l}\text { Understand the techniques and } \\
\text { strategies to realize ideas into } \\
\text { action (business start-up) }\end{array}$ & $\begin{array}{l}\text { Understand various } \\
\text { aspects of business } \\
\text { management and } \\
\text { functions }\end{array}$ \\
\hline
\end{tabular}

After knowing the purpose of making the model, a basic model is developed to improve the quality of entrepreneurship learning through technology-based business incubators, which are described as Figure 5.

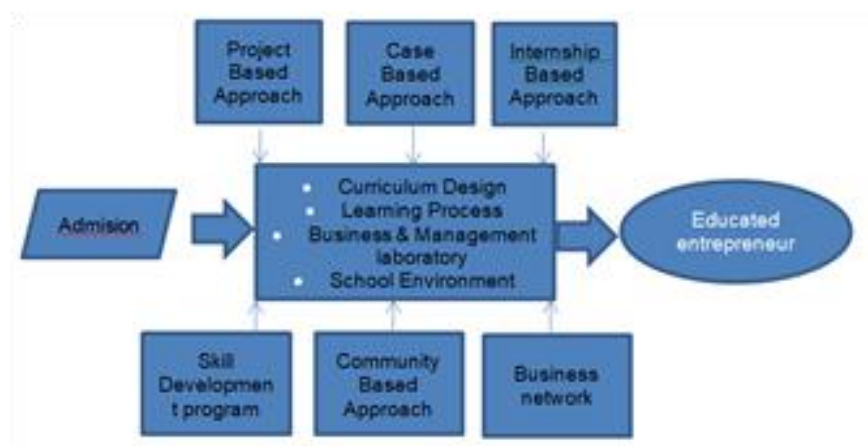

Fig. 5: Basic Model of Quality Improvement of Learning

The next process is to realize the basic model to the learning model through technology-based business incubators through stages of activities that train students who take entrepreneurship courses in order to produce "new" entrepreneurs who are able to identify opportunities, innovate (persistent) pursuit of goals, courage to see risk and deal with it through analysis. The implementation process of the activity is summarized in Table 2 .

Table 2: Implementation of learning activities through Technology-based Business Incubators

\begin{tabular}{|c|c|c|c|c|}
\hline & \begin{tabular}{l}
\multicolumn{3}{c}{ Session } \\
1234
\end{tabular} & $\begin{array}{llll}5 & 6 & 7 & 8 \\
\end{array}$ & $\begin{array}{llll}9 & 10 & 11 & 12\end{array}$ & 13141516 \\
\hline $\begin{array}{l}\text { Big } \\
\text { map } \\
\text { ping }\end{array}$ & $\begin{array}{l}\text { Scanning, } \\
\text { Identifying } \\
\text { and analyz- } \\
\text { ing Oppor- } \\
\text { tunity }\end{array}$ & $\begin{array}{l}\text { Understanding } \\
\text { About Entre- } \\
\text { preneurship } \\
\text { Experiencing } \\
\text { the entrepre- } \\
\text { neurial pro- } \\
\text { cesses }\end{array}$ & $\begin{array}{l}\text { Accelerated } \\
\text { integrated of } \\
\text { entrepreneur- } \\
\text { ship }\end{array}$ & $\begin{array}{l}\text { Experienc- } \\
\text { ing being } \\
\text { entrepre- } \\
\text { neur }\end{array}$ \\
\hline $\begin{array}{l}\text { The } \\
\text { me }\end{array}$ & $\begin{array}{l}\text { Creativity } \\
\text { Program }\end{array}$ & $\begin{array}{l}\text { Foundation } \\
\text { Program }\end{array}$ & $\begin{array}{l}\text { Establishing } \\
\text { Entrepreneur- } \\
\text { ship program }\end{array}$ & $\begin{array}{l}\text { Hatchery } \\
\text { program }\end{array}$ \\
\hline $\begin{array}{l}\text { Par- } \\
\text { tici- } \\
\text { pant }\end{array}$ & All student & & $\begin{array}{l}\text { Evaluate; } \\
\text { selective } \\
\text { student that } \\
\text { have high } \\
\text { entrepreneur- } \\
\text { ial character } \\
\text { and motiva- } \\
\text { tion }\end{array}$ & $\begin{array}{l}\text { Establish- } \\
\text { ing start up } \\
\text { new ven- } \\
\text { ture }\end{array}$ \\
\hline $\begin{array}{l}\mathrm{Ob}- \\
\text { jec- }\end{array}$ & $\begin{array}{l}\text { Small } \\
\text { business }\end{array}$ & $\begin{array}{l}\text { Project Busi- } \\
\text { ness }\end{array}$ & $\begin{array}{l}\text { Comprehen- } \\
\text { sive Business }\end{array}$ & \\
\hline
\end{tabular}




\begin{tabular}{|l|l|l|l|l|}
\hline $\begin{array}{c}\text { tive } \\
\text { out- } \\
\text { put }\end{array}$ & plan & & Plan & \\
\hline & & & $\begin{array}{l}\text { Upgrading I } \\
\text { Foundation } \\
\text { business } \\
\text { project }\end{array}$ & $\begin{array}{l}\text { Upgrading } \\
\text { II Founda- } \\
\text { tion Busi- } \\
\text { ness project }\end{array}$ \\
\hline
\end{tabular}

The learning pattern developed at this stage, when viewed from the learning needs of students, it seems that the whole learning activity is directed to the satisfaction of student learning, facilitating lecturers as implementing learning. Based on this reality, it appears that the learning model through technology-based business incubators not only maximizes the participation or involvement of students during learning, but has significantly improved lecturer performance in all aspects of ability and learning skills. In the context of this study, the use of modules, images, clippings and concept charts developed by the lecturer through technology throughout the learning process is very helpful for students in understanding the main concepts of the material, and the actual business issues or problems in their community. Through the activities of solving business problems directly in learning activities by using the generalization concepts that have been learned, it will eliminate students' negative attitudes towards learning done by lecturers [18]. Thus, the findings of this study seem to be quite effective in increasing the motivation and learning culture of students in the entrepreneurship subject as one of the subjects that have been considered to be unable to create educated entrepreneurs.

Through four stages (1) creativity program (2) foundation Program (3) establishing entrepreneurship program (4) hatchery program from 105 students participating through technology-based business incubators to achieve the Hatching Program for only 27 students or $25 \%$, and as many as 78 students can reach entrepreneurship program or as much as $75 \%$. This finding shows that the stages of becoming an entrepreneurial learning model can be realized through technology-based business incubators.

Based on the testing that has been carried out in this activity, it can be stated as follows:

a. Organizing the design activities of technology-based business incubator models in entrepreneurship courses, the stages of model development have been carried out starting from the need's analysis stage, then continued with the design of models implemented in the form of lecture prototypes through prototype technology-based business incubators designed and has fulfilled the use case in the learning system and other aspects.

1) Adapting teaching materials. Teaching materials are holistic in nature where knowledge, skills and values (values) are integrated with the needs in this information age. The curriculum is a competency-based curriculum

2) Make a variety of ways of teaching to achieve the basic competencies you want to achieve with the help of computers, the Internet

3) Conduct assessments using existing technologies (using computers, online assessment systems); and

4) Provide adequate learning materials such as books, computers, multimedia, studios, labs, etc. Learning material stored on a computer can be accessed easily by both lecturers and students

b. Based on point number 1 then each introduction of a particular technology utilization, there are four things that need to be prepared, namely.

c. This model allows the occurrence of individuation, acceleration, enrichment, expansion, effectiveness and productivity of learning which in turn will improve the quality of education as an infrastructure for developing human resources as a whole

d. Through this learning model, each student will be stimulated to learn to progress continuously in accordance with his potential and skills. Besides this, model requires creativity and self-reliance to enable it to develop all its potential. e. Through this learning model, students will obtain various information related to the subjects developed, as well as in a broader and deeper scope so as to improve their insights. This is a stimulus that is conducive to the development of student independence, especially in terms of developing competence, creativity, self-control, consistency, and commitment both to themselves and to other parties.

f. The model makes it easy for teachers to provide lecture materials and assignments.

\section{Conclusion}

In this study, one proposed learning model through a technologybased business incubator has been implemented and evaluated. The evaluation results show that this model can improve understanding, experience, and motivation to become entrepreneurs through Entrepreneurship courses

\section{References}

[1] Markley, D. M., \& McNamara, K. T. (1995). Economic and fiscal impacts of a business incubator. Economic Development Quarterly, 9(3), 273-278.

[2] Sherman, H., \& Chappell, D. S. (1998). Methodological challenges in evaluating business incubator outcomes. Economic Development Quarterly, 12(4), 313-321.

[3] Bøllingtoft, A. (2012). The bottom-up business incubator: Leverage to networking and cooperation practices in a self-generated, entrepreneurial-enabled environment. Technovation, 32(5), 304 315.

[4] Carayannis, E. G., \& Von Zedtwitz, M. (2005). Architecting gloCal (global-local), real-virtual incubator networks (G-RVINs) as catalysts and accelerators of entrepreneurship in transitioning and developing economies: Lessons learned and best practices from current development and business incubation practices. Technovation, 25(2), 95-110.

[5] Malek, K., Maine, E., \& McCarthy, I. P. (2014). A typology of clean technology commercialization accelerators. Journal of Engineering and Technology Management, 32, 26-39.

[6] Pena, I. (2004). Business incubation centers and new firm growth in the Basque country. Small Business Economics, 22(3-4), 223-236.

[7] Ratinho, T., \& Henriques, E. (2010). The role of science parks and business incubators in converging countries: Evidence from Portugal. Technovation, 30(4), 278-290.

[8] Sofouli, E., \& Vonortas, N. S. (2007). S\&T Parks and business incubators in middle-sized countries: The case of Greece. Journal of Technology Transfer, 32(5), 525-544.

[9] Tötterman, H., \& Sten, J. (2005). Start-ups: Business incubation and social capital. International Small Business Journal, 23(5), $487-$ 511 .

[10] Von Zedtwitz, M., \& Grimaldi, R. (2006). Are service profiles incubator-specific? Results from an empirical investigation in Italy. The Journal of Technology Transfer, 31(4), 459-468.

[11] Fayolle, A., \& Gailly, B. (2008). From craft to science: Teaching models and learning processes in entrepreneurship education. Journal of European Industrial Training, 32(7), 569-593.

[12] Ana, A., Hurriyati, R., Rostika, Y., \& Nazeri, M. (2016). Entrepreneurial intentions of tourism vocational high school students in Indonesia and Malaysia. Journal of Technical Education and Training, 8(2), 12-20.

[13] Gerstner Jr, L. V. (1995). Reinventing education: Entrepreneurship in america's public schools, and the special role of business in catalyzing educational change. Multimedia Today, 3(4), 24-29.

[14] Heinonen, J., \& Poikkijoki, S. A. (2006). An entrepreneurialdirected approach to entrepreneurship education: Mission impossible? Journal of Management Development, 25(1), 80-94

[15] Edwards, L. J., \& Muir, E. J. (2012). Evaluating enterprise education: Why do it? Education+ Training, 54(4), 278-290.

[16] Draycott, M., \& Rae, D. (2011). Enterprise education in schools and the role of competency frameworks. International Journal of Entrepreneurial Behavior and Research, 17(2), 127-145.

[17] Lessem, R., \& Baruch, Y. (1999). Colour your managerial type, colour your organization. Career Development International, 4(1), 11-18. 
[18] McComas, J., Pivik, J., \& Laflamme, M. (1998). Children's transfer of spatial learning from virtual reality to real environments. CyberPsychology and Behavior, 1(2), 121-128.

[19] Heinonen, J. (2007). An entrepreneurial-directed approach to teaching corporate entrepreneurship at university level. Education + Training, 49(4), $310-324$

[20] Smilor, R. W. (1987). Managing the incubator system: Critical success factors to accelerate new company development. IEEE transactions on Engineering Management, 34(3), 146-155.

[21] Smilor, R. W., \& Feeser, H. R. (1991). Chaos and the entrepreneurial process: Patterns and policy implications for technology entrepreneurship. Journal of Business Venturing, 6(3), 165-172.

[22] Smilor, R. W., Gibson, D. V., \& Dietrich, G. B. (1990). University spin-out companies: Technology start-ups from UT-Austin. Journal of Business Venturing, 5(1), 63-76.

[23] Temali, M., \& Campbell, C. (1984). Business incubator profiles: A national survey. Hubert H. Humphrey Institute.

[24] Chou, C. M., Shen, C. H., \& Lee, Y. J. (2007), A study on enterprise, employment terms and competencies for technological and vocational school graduates Taiwan. In World Transaction on Engineering and Technology Education, pp. 301-308

[25] Clausen, T., \& Korneliussen, T. (2012). The relationship between entrepreneurial orientation and speed to the market: The case of incubator firms in Norway. Technovation, 32(9-10), 560-567.

[26] Kim, H., \& Ames, M. (2005). Business incubators as economic development tools: Rethinking models based on the Korea experience. International Journal of Technology Management, 33(1), 1-24.

[27] Gibb, A. (1999). Can we build effective entreupreuneurship through management development. Journal of General Manager, 24(4), 1-21. 